\title{
Participative Evaluation and the Quality of Community Empowerment Training of Program Keluarga Harapan (PKH) Companions
}

\author{
Ach. Rasyad \\ Universitas Negeri Malang, Indonesia \\ E-mail: rasyadplsum@yahoo.co.id
}

Received: 23-02- 2016

Accepted: 25-04-2016

Published: $30-04-2016$

doi:10.7575/aiac.ijels.v.4n.2p.39

URL: http://dx.doi.org/10.7575/aiac.ijels.v.4n.2p.39

\begin{abstract}
This research is aiming at describing: (1) the implementation of community empowerment training of PKH companions, (2) types of participative evaluation used in the PKH companion training, and (3) obstacles and supporting factors in PKH companion training using the participative evaluation. The study employed qualitative approach with case study framework. It was conducted in PKH companion training in Klojen district, Malang. The subjects of this research were companions as facilitators of the community empowerment training. The data collection was carried out by deep interview, focus group discussion, observation, and documentation. The data obtained were reduced according to the objectives of the research. Later on, it was presented in description of fact, then conclusion or verification was drawn. The finding of the research showed: (1) the learning method used in the PKH companion training was andragogy approach which emphasized on active participation and participants' experiences, (2) the evaluation employed in the PKH companion training was participatory rural appraisal (PRA) method by conducting focus group discussions (FGD) and questionnaires, (3) the weakness of employing this participative evaluation was it took relatively long time and the discussion tended to be out of the context. Meanwhile, the strength of the participative evaluation was the openness of information which made the training participants feel the democratic atmosphere during the training evaluation process.
\end{abstract}

Keywords: Participative evaluation, Training quality, Community empowerment, Program Keluarga Harapan

\section{Introduction}

These days, knowledge and technology are rapidly developing. This phenomenon demands human beings' needs to be advanced as well. The more the needs emerge, the faster they demand to be fulfilled. One of the needs is the need of education. In the law number 20 year 2003 about the National Education System, it is explained that Indonesian education consists of three types, namely formal, non-formal, and informal educations. Those three are needs that are important to be fulfilled by everyone during their life. When the education need is fulfilled, they have knowledge, skills, and positive attitude, so they are able to adapt to the development of community's needs.

Indonesia is one of developing countries in Southeast Asia developing in all aspects. Nowadays, there is a lot of homework to reduce the poverty level in Indonesia. The high level of poverty makes the government work harder. There are several governmental programs issued to solve the poverty problem. However, in fact, those programs have not been able to give significant effect so that the objectives of national development related to community welfare's equitability still becomes an endless matter (Utomo et al., 2014).

To solve the poverty problem, we need to empower the independent community. Through the community empowerment program, the community not only get helped in the form of materials, but also in the form of mindset to improve themselves. UNDP (2009) states:

Traditionally, RBM (Result-Based Management) approaches have focused more on internal results and performance of agencies than on changes in the development conditions of people. RBM is defined as a broad management strategy aimed at achieving improved performance and demonstrable results.

These days, the Social Ministry is developing some programs in health and education aspects contributing to the achievement of Millennium Development Goals. To realize the project, the central and local governments create Program Keluarga Harapan (henceforth PKH) focusing on the health and education services. The target of PKH is destitute families in every corner of the country.

$\mathrm{PKH}$ is one of governmental programs aiming at reducing the poverty level. PKH highlights on the health and education services, particularly for destitute families whose children are in school age up to junior high school as well as pregnant and breastfeeding mothers. Consideration of highlighting the program in the health and education aspects is the 
existence of positive correlation between the health and education to the community's approval in their needs' fulfillment. As a result, the poverty level of families is closely related to their health and education level. The low income of the destitute family leads to the inability to fulfill their health and education needs.

To help the PKH succeed, skilled companions are required as the program movers. They have to join trainings to obtain experiences when they work in the field. The training for the PKH companions is beneficial to improve the human resources quality involving in the $\mathrm{PKH}$. Therefore, $\mathrm{PKH}$ companion training is targeted to all central and local companions. The training is one of non-formal education types. There are a lot of trainings carried out by institutions, organizations, and companies in order to improve their knowledge, skill, and attitude so that they are able to perform their best to achieve the goals of the institutions, organizations, and companies. Cartwright (2003: 49) utters that training aims at making the staffs have better performance, able to work better in the future, and develop comfortably along with the institution.

According to Philip (1991), a training is an activity designed to improve the staff performance to do their current work. Unfortunately, not all trainings are run based on the training procedure. One of important aspects in the training is evaluation. Training with evaluation aspect can give many benefits. This is in line with Hamalik (2001: 127) who says that a training program needs to be evaluated continuously from all aspects, such as its relevance to the needs, effectiveness, benefits, obstacles, profits, and administration so that it is clear whether the training is successful or it is needs to be either improved or maintained.

To watch if PKH companion training has met the designed objectives, an evaluation is required. The evaluation is used to assess the gap between the standard and the reality (Provus, 1971). This gap is used as an indicator of how far the activity runs; whether or not it is in line with the plans. Based on Stark \& Thomas (1994), processes that provide information about individual students, about curricula or programs, about institutions, or about entire systems of institutions.

The evaluation is closely related to the assesment of relevance, performance, effectiveness, and effect of an activity related to the time, area, or population. The evaluation is a periodic procedure that is done to assess the product, and to see if an activity has met the main goal. The evaluation becomes a measurement tool to manage and make decision. The measurement means the process by which information about the attributes or characteristics of thing are determined and differentiated (Oriondo \& Antonio, 1998). When evaluation has been conducted, the improvement has to follow. According to Griffin \& Nix (1991),

Measurement, assessment, and evaluation are hierarchical. The comparison of observation with the criteria is a measurement, the interpretation and description of the evidence is an assessment and the judgment of the value or implication of the behavior is an evaluation.

In the management terminology, the function of evaluation is to plan, organize, and execute. In the training, the human resources development strategy needs an evaluation. The evaluation in the training is needed to see the effectiveness of the training. If the evaluation is well-conducted, many sides will get the benefit. For example, a training which applies evaluation will be able to see their strength and weakness.

To guarantee the training's transparency, monitoring from many parties is needed, particularly from the training program level as the benchmark of the community's sense of belonging towards the program. The attempt to manage the program to make the community active in the monitoring is needed by many parties, including the community themselves. The program manager needs to communicate the follow up action resulted from problems submitted by any parties.

Evaluation can also be carried out by assessing the outcome and the effect of the training; whether it is according to the goal and plans. The evaluation will be conducted in the middle and after the training. Based on experiences, there are some evaluation tools have been used and adjusted to certain situation and needs. However, the most important thing in the evaluation is the follow up attempt to improve continuously (Nasrul, 2009).

Conducting a participative training program is no different with managing a certain program. The problem is, training is seen as something ordinary and some parts are deliberately removed from the process. Nasrul (2009) states that many parties give more attention to and prioritize the physical project than project of developing human resources through training.

This research is conducted to see the implementation of the participative evaluation related to the community empowerment training to improve the training quality. In addition, this research also attempts to portray the evaluation process and unwanted deviations so that it can be improved to achieve the goals of the activity. (Terry, 2009).

\section{Methods}

This research employed qualitative approach. The reason of using the approach was, according to Arifin (2003), the research object was the process, activities, or actions which needed to be observed deeply with natural background. Besides, the qualitative approach needed some processes to search for the meaning out of observed phenomenon. The designed case study was one case study in the PKH companion training in Klojen district, Malang. Next, the problem to solve in this case study was the participative evaluation process done in PKH companion training. 
As the research employed qualitative approach, the researcher was demanded to be objective to see the fact in the field. Consequently, the researcher attempted to work naturally and objectively during the data collection process by conducting interview, observation, and documentation. The qualitative research has to be naturalistic; meaning that the researcher cannot manipulate the program or policy (Patton, 2009).

Bogdan and Biklen (2003) suggested the case study framework should be in the funnel form. The funnel was systematic because it started from a wide and deep exploration and continued to data collection which was specific and directed. The objective of this research was to describe in details the empirical reality in a phenomenon; therefore the qualitative approach in this research matched the empirical reality with the theory of descriptive method (Moleong, 2006).

The research setting was PKH in Klojen district, Malang. The consideration of choosing this location was: (1) not all PKH companion training had participative evaluation process, (2) the success benchmark of community empowerment training could be reflected from its evaluation process, and (3) to see how well the implementation of community empowerment training in health and education aspects.

The data collection process was carried out by some methods, namely thorough interview, focus group discussion, and documentation. The method in the data collection had to fit the nature and characteristic of the research (Zuriah, 2006). The data analysis technique employed was making analysis plan, interpreting the finding, drawing conclusion, making recommendation, and concluding the lesson learned from the evaluation process. The data obtained would be reduced based on the research objectives. It would be presented in the form of description of facts, and conclusion or verification would be drawn. The approach was inductive, meaning that the evaluator used their logic to face a situation with no expectation regarding to the program background (Patton, 2009).

\section{Findings}

\subsection{The Implementation of Community Empowerment Training of PKH Companions}

The role of companions in PKH program was very significant to assist the acceleration process for the destitute family to be independent out of the poverty. The companion's role was not merely about administration matters, regular meetings, and PKH monitoring without any supervision. The PKH companions had to be able to play roles as friends, family, mediator, informant, and facilitator. A good companion was able to understand and know well about the real condition of their target. A good companion would bridge the programs they planned with the targeted community. After the targeted community has been able to be independent and did not depend on the assistance anymore, the assisting function was still required to motivate the targeted community to improve their quality of life.

The existence of the community empowerment companion was needed by the destitute families as most of them were still unable to strive for their rights. Therefore, they needed ones to save, motivate, facilitate, bridge, and represent them as well as fulfill any obligation in PKH. PKH companion's position was quite important and strategic for they invested their time to strive in the behalf of the destitute family out of their limitation.

According to these matters, candidates of PKH companions in 2015 were provided by any knowledge and skills related to assisting the destitute family of PKH. It was expected that the basic need of the destitute family, particularly in health and education aspects, could be fulfilled properly. The other expectation was there would be some progressively dynamic attitude and behavior of the destitute family to live their lives.

PKH was a program initiated by the Government to reduce the poverty level by interfering the destitute family in terms of health and education aspects. This program was expected to be able to cut the poverty chain through the existence of health and education facilities for pregnant mothers and school-age kids. Unfortunately, the assistance which required the targets to obey to access the health and education facilities has not met the objective optimally. This was reflected from the low health maintenance of pregnant mothers, improper caring of kids under two, poor awareness of the benefit of breastfeeding, and poor family behavior towards children. The worse was, this ignorant behavior towards the importance of health and education was due to the low education level and limited access to information and knowledge.

There were many destitute families who could not afford the health and education facilities because of their low income. Meanwhile, problems regarding to supply which led to the low access to health and education access were 1) the service cost was unaffordable, 2) the distance between the house and the service location was relatively far, 3) the bad timing of the service made the families prioritized other more important activities.

To achieve the PKH objective as soon as possible, Family Development Session (FDS) program was highly needed. FDS stage consisted of assessment, planning, and implementation which involved some ministries and other institutions (Bappenas, Health Ministry, World Bank, UNICEF, and Australia Aid) related to poverty. FDS aimed at improving the destitute family's awareness to manage their family financial condition, education, economic, health, and taking care of their children independently.

FDS was carried out by assistance process in monthly meeting. The PKH companions not only played the role of monitoring of the destitute family, but also became facilitators. To improve the capacity of PKH companions so that they were able to be FDS facilitators to accelerate the fulfillment of PKH achievement, the social ministry conducted FDS PKH training. 
To carry out the sustainable PKH program, it was important to prepare companions who possessed knowledge, skill, and positive attitude to access the program. This kind of companion could be shaped in the FDS companion training. However, the success of the training highly depend on the willingness and capability of the training participant to understand, acquire, and develop materials they achieved in the training and applied them to the practical thing in their areas.

The PKH companion training was conducted in some period of time and it was done in seven days with 60 hours duration. The training material was divided into three categories, namely 1) Basic training material (Group Dynamic and Policy to Solve Poverty in Social Protection's Perspective), 2) Main training material (PKH Basic Values, Social Assisting Ethics, PKH Knowledge, Family Development, Motivation Development, Effective Communication and PKH Social Assisting, Coordination and Network Development, Method and Technique of Assisting, and Field Study Practice), and Supporting training material (Introduction, Evaluation, Pre-Test, Post-Test, Evaluation and Report, and Closing).

Learning method employed in the PKH companion training was andragogy approach in which it emphasized on the active participation and participant's experience utilization. The andragogy approach principles which needed to be highlighted were as followed. First, learning by doing. Second, realistic case studies and they were relevant to the participant's knowledge and experience. Last, the use of learning media which enabled the five senses stimulation.

\subsection{Identification of Participative Evaluation Types Used in the PKH Companion Training}

The aim of the PKH companion training evaluation was to see if the training result was as expected, to identify the sustainability of programs and their results, and to see the effectiveness of the training strategy; whether it was according to planning or not.

According to evaluation questions given by the training committee to the training participant, the evaluation form done in the PKH companion training was 1) Participatory Rural Appraisal (PRA) technique by Focus Group Discussion (FGD) as there were question items asking the participants about the open analysis, 2) Questionnaire that was distributed to the participant as answers to certain questions chosen by using certain scale. Some components being evaluated in the PKH companion training were training planning (objectives, targets, activities, and schedule), training implementation, and achieved results.

The use of two evaluation tools had their own strength and weakness, but by combining some evaluation techniques, it was expected to draw highly valid, trusted, and legal conclusion.

The evaluation process was carried out throughout the training and before the closing. Based on the research finding, there were three dominant aspects that were evaluated in the PKH companion training. Firstly, the evaluation to the PKH companion training was conducted by using PRA technique and questionnaire asking about: 1) the level of participant's learning achievement (the capability of participants in cognitive, affective, and psychomotor aspects), 2) the level of participant's responses towards the training implementation in all aspects, 3) the performance level which was the participant's capability to fulfill the duty given by the facilitators, and 4) effects of the training to the training participant.

Secondly, the evaluation to the informant or facilitator was carried out by distributing the questionnaire to the participant in order to assess the informant or facilitator's performance from some aspects, namely mastery of the material, presentation systematic, capability of presenting the material, the material's relevance to the learning objective, the use of learning method, the use of language, tone and voice, the style of answering participants' question, attitude and behavior, how to motivate the participant, teamwork between facilitators, and presence.

Last, the evaluation for the PKH companion training committee. This evaluation was carried out by distributing questionnaire and open questions to the PKH companion training participants. Some aspects being asked namely the effectiveness of the training, training facilities, the suitability of training implementation with the planning, the relevancy of materials and training objective, the cleanliness of the training place, and the committee service.

\subsection{The Obstacle and Supporting Factors in PKH Companion Training Using Participative Evaluation}

Throughout the PKH training process, the committee of the training employed the participative evaluation to obtain some post-training feedbacks. During the use of the participative evaluation, there were some obstacles as well as supporting factors. Some obstacles found in using the participative evaluation were 1) the duration for Participatory Rural Appraisal (PRA) was exceed the schedule, 2) the participants did not come on time, so the participative evaluation process was delayed, 3) not all participants were actively involved in the Focus Group Discussion (FGD), 3) the participative evaluation was not carried out based to the schedule, and 4) the number of the committee carrying out the participative evaluation was limited.

Meanwhile, the supporting factors in the participative evaluation in the PKH companion training were as follows 1) high motivation, responsibility, cooperation, and dedication of the participants, 2) skilled facilitators in facilitating the Forum Group Discussion (FGD) activity, 3) complete and standardized evaluation instrument given to the participants in the form of questionnaire, and 4) the existence of facilities which supported the participative evaluation process.

Based on the evaluation result, some aspects which made the participants satisfied with the training were the varied menu of food provided during the training and good accommodation for the training participation. In the process of 
PKH companion training, the trainers were from well-known organization and they were experts in their field, such as trainers from Social Services of East Java Province, structural officers from institutions in charge of PKH, and some informants from Social Services. Therefore, materials given in the training were beneficial and well-applied in the areas. Moreover, motivated, responsible, cooperated, and dedicated participants attempted to apply the materials and they got supported by the facilitators and training committee. The effective communication among the committees, facilitators, participants, and related parties as well as the support from the Social Services also became the supporting factors of the training.

During the training process of $\mathrm{PKH}$ companions, all activities went well including the evaluation process. The evaluation was carried out within two stages: throughout the training and after the training. Throughout the training, the evaluation made was about the participant, informant, and committee. While after the training, direct observation was done and questionnaire was distributed to the training participant.

\section{Discussion}

\subsection{PKH Companion Training}

To make the PKH program successful, skilled companions were required. All skilled PKH companions in each regency or city and district had to possess capability and skill to perform on assisting duty to the destitute family who were the target of the program. They also had to make the PKH program ran smoothly. They were recruited by Unit Pelaksana Program Keluarga Harapan (UPPKH) through some selection process and training. After the recruitment process, they had to join a PKH companion training in order to provide them with skill and knowledge needed to face problems in the field.

Due to the complex responsibility of PKH companions, the training for PKH companions had to be conducted. This training was expected to be able to help the training participant directly to apply the knowledge they obtained in the class, give positive contribution to every obstacle, as well as enrich their knowledge, attitude, and experience about the implementation of PKH in the field.

Generally, the PKH companion training aimed at accelerating the achievement of MDG target. While particularly, its objective was to improve the understanding, knowledge, and capability, as well as skill of PKH executors. Other aims were to prepare the training participant to perform some duty related to the PKH program implementation, understand the policy of reducing the poverty in social protection's perspective, understand and apply the flow and mechanism of $\mathrm{PKH}$, motivate $\mathrm{PKH}$ participant to improve their quality of life, realize and understand the basic values of PKH, understand the social assisting ethic, describe the mechanism of health and education services in PKH, apply the effective communication technique in social assisting in $\mathrm{PKH}$, apply the assisting technique and group dynamic, and encounter obstacles in their duty in the field.

To see the effectiveness of the PKH companion training, the evaluation process needed to be conducted. Evaluation process played a significant role in the training process. Fakhriah (2010) stated that PKH evaluation aimed at seeing the PKH effect towards the utilization of health and education services by the destitute family, as well as its effect to the health and education infrastructure provision done by the Local Government which led to the contribution of MDGs target achievement.

The evaluation outcome from the PKH companion training could be a measurement tool to determine the policy of $\mathrm{PKH}$ program in the future. It could also be used to see the effect of the training. The evaluation research discussed two dimensions. First, it was about how a policy could be measured based on the assigned objectives. Second, it was about the actual effect from the policy (Parsons, 2008).

\subsection{Types of Participative Evaluation}

The term "participative evaluation" referred to the process of assisting clients or audiences to justify the advantages of programs (worth) and use the justification results to formulate recommendation about the program improvement. A training would have more complete process if they could use a suitable evaluation process. An effective training program begins with an honest assessment of the needs of the organization and the individual employee (Westover, 2008). The participative evaluation was meant to give directions to facilitator of evaluation to help their client to evaluate their program, especially about program outcome. The word "outcome" referred to a reality or actualization in every stage of program development which included context, input, process, and program output.

The participative evaluation model could be designed and used to evaluate training programs. Basically, every training program needed an evaluation process. In order to insure that adults are learning effectively, training programs must be evaluated (Westover, 2008). The evaluation result could be used as a benchmark whether a training was successful or not. The study of the participative approach model in literature or reality aspects could be used to complete the existing evaluation forms. This following course included participative factors (characteristics) and evaluation design have been completed. If this model would be implemented to evaluate programs other than training, some minor changes should be adapted.

Evaluation was an activity done systematically to assess and measure the relevance, effectiveness, efficiency, and effect of a program based on certain criteria. Evaluation was not meant to assess personal performance or institution capacity. In the training process, evaluation played a significant role for all sides (committee, executor, participant, and parties 
related to the $\mathrm{PKH}$ ) to see the development process of $\mathrm{PKH}$ training as well as learning process occurred in the training. Rachmawati (2015) proposed that a training evaluation was an important component in a training system. Without any evaluation, one would not know if a training program done by certain training institution was successful or not. The advantages of participative evaluation in $\mathrm{PKH}$ companion training were reducing the risk of loss of PKH companion training, improving the effectiveness and efficiency principles in $\mathrm{PKH}$ companion training, obtaining maximum results, and gaining skills as expected.

Generally, the evaluation done in the PKH companion training was focused on the evaluation of outcome and process. The evaluation of PKH companion training's impact did not appear in this training. This was due to the evaluation of impact tended to see changes in positive or negative sides of individual, institutions, and environment caused by the development activities, such as programs or projects. The evaluation of impact not only measured if the objective has been achieved or assessed the direct effect towards the advantages receivers. The evaluation of impact could be recognized from the learning outcome during the participant joined the training. The evaluation of impact also gave substantial basis to higher level of evaluation (UNDP, 2009).

Meanwhile, the evaluation of process was carried out throughout the training. This evaluation of process was an activity done for the sake of achieving the objectives or performance so that the input could lead to specific results. The evaluation of process was related to the efficiency of program which included the relationship among the committees and the training participants, communication media, logistics, resources, training schedule, and potential factors leading to failed program (UNDP, 2009).

The fundamental reasons of why evaluation must be done were as follows: 1) the evaluation was used to watch the development of a program, 2) the evaluation could show the program effectiveness, particularly the cost effectiveness, 3) the evaluation would provide feedback to anyone involving in the program, 4) the evaluation ensured the commitment to every action taken, 5) the evaluation fixed the accountability in the management level through the management report about the input, process and outcome to the policy makers, community, and stakeholders, 6) the evaluation understood how a program ran, 7) the evaluation gave lessons and improved the decision, planning, and action in the future, 8) the evaluation could determine if the objective has been achieved by the program initiative, 9) the evaluation assessed the impacts, and 10) the evaluation was a guideline to run a program.

The evaluation model appeared in the PKH companion training showed two kinds of models, they were summative and formative evaluation models. The summative evaluation in the PKH companion training was indicated by an action to compare the objectives and the achieved outcome. The evaluation conducted in the training attempted to see if the training was successful. Therefore, the summative evaluation was carried out by comparing the initial objectives and the achieved outcome.

Besides applying the summative evaluation, the committee of the training also employed the formative evaluation model. This kind of evaluation was carried out to see the process of the training in order to give feedback to the committee of the training program. The formative evaluation was conducted throughout the process of the training. This formative evaluation was aimed at seeing how far the plan went as well as identifying the obstacle occurred during the training. By having the formative evaluation, the obstacles and factors made the training unable to run smoothly could be identified. Furthermore, this evaluation model enabled the training committee to detect the weakness of the training earlier, so they could improve it sooner so that the training could run well.

\subsection{The Advantage of Participative evaluation}

The characteristic of the participative evaluation in the training could be identified from several indicators. First, the planner and executor of process. The participative evaluation always involved the community, committee, facilitator, and stakeholder. Second, the role of main stakeholder. The main stakeholder played a role to design and adapt the methodology, collect and analyze data, spread the findings, relate to their action, and participate. Another indicator was the success measurement. The success indicator was determined internally, including the qualitative assessment. Forth, the more adaptive approach. Next, the focus of the learning process. And last, the participative method conducted.

The PKH companion training employed an evaluation with participative approach as in the training process, the process design allowed the related parties to involve directly to analyze the data.

Armitage (2012) states evaluation has been presented as a means to judge the course effectiveness for a range of interested parties and for a similar range of reasons. During the training process, a lesson should have been a base for every improvement and correction in the future. The use of participative evaluation in the training took some relatively longer time as it needed deepening and negotiation to meet the agreement about what to evaluate, how and when the data collected and analyzed, the meaning of the data collected, and how the finding would be spread and followed up.

Basically, there was nothing such the best evaluation tool to be applied in any kinds of training. Each existing evaluation tool had their own strength and weakness. So did the participative evaluation. If seen from the process, the weakness of the participative evaluation was it took relatively long time to obtain deep outcome. It was because the evaluator needed natural response from the training participant. However, this evaluation model had some strengths, such as it could obtain deep outcome, the evaluation resources not only the stakeholder, but also the training participant, the training participant were involved directly in the evaluation, and the evaluation outcome was not made by certain 
party only. Evaluation is all about finding out if our new course is working properly. This, of course, is what Ofsted means by 'self-evaluation' which lies at the heart of their inspection methodology (Armitage, 2012).

Some advantages of the participative evaluation were as follows. First, the decision making was done democratically. It meant, in the evaluation process, the evaluation questions or techniques employed to collect and analyze the information were not initially determined by the evaluator (Rippey, 1973; Stake, 1976, 1983). The second advantage was it could improve and make the program more efficient. Another advantage was the collaboration of the evaluation facilitator and participants. This condition made the training facilitator have the same position with the evaluation facilitator. Despite their positions, they have got different duties. Next, the interactive communication. Everyone could express their ideas based on the objective of each evaluation part and analyze the information and ideas given. Fifth, openness of information from the training participants. Openness was one of components to succeed in the participative evaluation. The training participant' direct involvement in the decision making was another advantage. This involvement in the decision making was useful as it could strengthen the participants' dignity. Last but not least, the training participant could control information they obtained. The training participants could keep their sense of belonging and vested interest towards the evaluation product.

\section{Conclusions}

The PKH companion training was conducted in seven days with 60 hours duration. The learning method employed in this PKH companion training was andragogy learning approach which emphasized the active participation and participants' experience utilization. The evaluation done in the PKH companion training was 1) Participatory Rural Appraisal (PRA) technique by conducting Focus Group Discussions (FGD) as some question items were open questions, and 2) questionnaire was distributed to the training participants as answers to some questions were chosen with certain scale.

Some obstacles found in the participative evaluation were as follows. First, the duration for Participatory Rural Appraisal (PRA) exceeded the schedule. Second, the participants did not come on time, so the participative evaluation process was delayed. Next, not all participants were actively involved in the Focus Group Discussion (FGD). Another obstacle was the participative evaluation was not carried out based to the schedule. And last but not least, the number of committee carrying out the participative evaluation was limited.

Despite the obstacle, the participative evaluation also have got some supporting factors, namely 1) high motivation, responsibility, cooperation, and dedication of the participants, 2) skilled facilitators in facilitating the Forum Group Discussion (FGD) activity, 3) complete and standardized evaluation instrument given to the participants in the form of questionnaire, and 4) the existence of facilities which supported the participative evaluation process.

\section{Recommendation}

PKH was a community empowerment program which is effective to reduce the poverty level. This program is able to help the destitute families to be more powerful and make them aware to wake up from the poverty. To improve the quality and quantity of the community empowerment training in $\mathrm{PKH}$ program, some points are suggested: 1) the more standardized participative evaluation tools enables the community to be better, and 2) some basic improvement regarding to the participative evaluation is also needed.

\section{Acknowledgement}

The researcher wants to thank (1) the director of Lembaga Penelitian dan Pengabdian kepada Masyarakat (LPPM) of Universitas Negeri Malang for helping the research, (2) the Dean of Faculty of Education, and (3) the review team for giving valuable suggestion and feedback to the researcher: Prof. Dr. Ach. Fatchan, M.Pd, M.P. and Prof. Dr. Bambang Budi Wiyono, M.Pd.

\section{References}

Arifin, A. (2013). Kepemimpinan Kepala Sekolah dalam meningkatkan Budaya Mutu. Ilmu Pendidikan. 40 (2): 111 117.

Bogdan, R. C. \& Biklen, S. K. (2003). Qualitative Research for Education: An introduction to Theories and Methods (4th Ed.). New York: Pearson Education group. (pp. 110-120).

Fakhriah, R. (2010). Evaluasi Dampak PKH terhadap Aksesibilitas KSM Mendapatkan Pelayanan Dasar Kesehatan \& Pendidikan, (Online), (http://www.kemsos.go.id/modules.php?name=News\&file=article\&sid=15939), diakses 28 September 2015.

Griffin, P. \& Nix, P. (1991). Educational Assesment and Reporting. Sydney: Harcout Brace Javanovich, Publisher.

Moleong, L.J. (2006). Metodologi Penelitian Kualitatif. Bandung: PT Remaja Rosdakarya.

Muchtar, E.H. \& Sutopo, M. (2010). Kegagalan SBY dalam Fakta dan Angka. Yogyakarta: Pusataka Fahima.

Nasrul, M. (2009). Evaluasi Program Pelatihan. Medik, (1): 39-44. 
Oriondo, L.L. \& Antonio, E.M.D. (1998). Evaluating oucomes (Test, Mesurement and Evaluation). Florentino St: Rex Printing Company, Inc.

Philip, J.J. (1991). Training Evaluation and Measurement Methods. Huston: Gulf Publishing Company.

Parsons, W. (2008). Public Policy: Pengantar Teori dan Praktik Analisis Kebijakan. Jakarta: Kencana Prenada Media Group.

Patton, M. Q. (2009). Metode Evaluasi Kualitatif. Yogyakarta: Pustaka Pelajar.

Provus, M. (1971). Dependency Evaluation. Berkeley, California: McCutchan Publishing Corporation.

Rachmawati, R. (2015). Evaluasi Pendidikan dan Pelatihan (Diklat) Model Kirkpatrick. (Online), (http://bdkjakarta.kemenag.go.id/index.php?a=artikel\&id=890), diakses 28 September 2015.

Rippey, R.M. (1973). Transactional Evaluation in the Woodlawn Experimental School Project. In R.M. Rippey (Ed.), Studies In Transactional Evaluation. California: McCtuchan Publishing, Berkely.

Stake, R.E. (1976). To Evaluate an Arts Program. Journal of Aesthetic Education, 10 (3-4), 115-133.

Stake, R.E. (1983). Program Evaluation, Particularly Responsive Evaluation. In G.F. Madaus, et al. (Eds.), Evaluation Models: Viewpoints on Educational and Human Services Evaluation. Boston: Kluwer Nijhoff Publishing.

Stark, J.S. \& Thomas, A. (1994). Assesment and Program Evaluation. Needham heights: Simon \& Schuster Custom Publishing.

Terry, R.G. (2009). Prinsip-Prinsip Manajemen. Jakarta: Sinar Grafika.

United Nations Development Programme. 2009. Handbook on Planning, Monitoring and Evaluating for Development Result. New York: A.K. Office Supplies.

Utomo, D., Hakim, A. \& Ribawanto, R. (2014). Pelaksanaan Program Keluarga Harapan dalam Meningkatkan Kualitas Hidup Rumah Tangga Miskin. Jurnal Administrasi Publik (JAP), (Online) 2 $\quad$ (1): 29-34, (http://download.portalgaruda.org), diakses 25 Desember 2015.

Westover, J.H. (2008). Effective Human Resource Training and Development: Examination and Application of Adult Learning Theory in the HR Management Context. The Journal of Human Resource and Adult Learning, 4 (1): 1-8.

Zuriah, N. (2006). Metodologi Penelitian. Jakarta: Bumi Aksara. 